\title{
TRADITIONAL INFANT MASSAGE IN BANJARMASIN, SOUTH KALIMANTAN
}

\author{
Indrayadi
}

Nursing Academy KESDAM/ VI Tanjungpura, Banjarmasin

\begin{abstract}
Background: Infant massage is a type of complementary and alternative treatment that uses massage therapy for human infants. This therapy has been practiced globally, and has been increasingly used in Western countries as a treatment for infants. The scientific evidence supporting its use is growing. This study aimed to describe the nature and stages of traditional infant massage in Banjarmasin, South Kalimantan.

Subjects and Method: This was a qualitative study using narrative conducted in Banjarmasin, South Kalimantan, in January 2018. The key informants included some famous traditional infant massagers. The data were collected by in-depth interview and observation.

Results: The study produced three themes: (1) Origin of abilities; (2) Stages in traditional infant massage; (3) Adjunctive therapy in traditional infant massage. The traditional infant massage had been used as an alternative terapy to cure fever in children. Holy water with verses sometimes was provided as an adjunctive therapy to the traditional infant massage.

Conclusion: Traditional baby massage is an alternative therapy to cure fever in children. It may be complemented with holy water with verses.
\end{abstract}

Keywords: infant massage, traditional, adjunctive therapy

\section{Correspondence:}

Indrayadi. Doctoral Program in Public Health, Universitas Sebelas Maret, Jl. Ir. Sutami No. 36 A, 57126, Surakarta, Central Java.

Email: ketikindrayadi@gmail.com Mobile: 085251050598.

Mid-International Conference in Public Health, Best Western Premiere Hotel, Solo, Indonesia, 18-19 April 2018 | 207 https://doi.org/10.26911/mid.icph.2018.03.43 